\title{
Trypanocidal activity of human plasma on Trypanosoma evansi in mice
}

\author{
Atividade tripanocida do plasma humano sobre Trypanosoma evansi em camundongos \\ Aleksandro Schafer Da Silva ${ }^{1 *}$; Marcos Rafael Kroeker Duck¹; Vinicius da Rosa Fanfa'; Mateus Anderson Otto'; \\ João Tomaz Schmitt Nunes ${ }^{1}$; Alexandre Alberto Tonin ${ }^{1}$; Jeandre Augusto Jaques ${ }^{1}$; Francine Chimelo Paim²; \\ Marta Maria Medeiros Frescura Duarte ${ }^{3}$ S Silvia Gonzalez Monteiro ${ }^{1}$
}

${ }^{1}$ Department of Microbiology and Parasitology, Universidade Federal de Santa Maria - UFSM

${ }^{2}$ Department of Small Animals, Universidade Federal de Santa Maria - UFSM

${ }^{3}$ Lutheran University of Brazil - ULBRA

Received July 11, 2011

Accepted January 21, 2012

\begin{abstract}
This study aimed to test an alternative protocol with human plasma to control Trypanosoma evansi infection in mice. Plasma from an apparently 27-year-old healthy male, blood type A+, was used in the study. A concentration of $100 \mathrm{mg} \cdot \mathrm{dL}^{-1}$ apolipoprotein L1 (APOL1) was detected in the plasma. Forty mice were divided into four groups with 10 animals each. Group A comprised uninfected animals. Mice from groups B, C and D were inoculated with a T. evansi isolate. Group B was used as a positive control. At three days post-infection (DPI), the mice were administered intraperitoneally with human plasma. A single dose of $0.2 \mathrm{~mL}$ plasma was given to those in group C. The mice from group D were administered five doses of $0.2 \mathrm{~mL}$ plasma with a 24 hours interval between the doses. Group B showed high increasing parasitemia that led to their death within 5 DPI. Both treatments eliminated parasites from the blood and increased the longevity of animals. An efficacy of 50 (group C) and 80\% (group D) of human plasma trypanocidal activity was found using PCR. This therapeutic success was likely achieved in the group D due to their higher levels of APOL1 compared with group C.
\end{abstract}

Keywords: Trypanosoma evansi, treatment, human plasma, APOL1.

\section{Resumo}

Este estudo teve como objetivo testar um protocolo alternativo com plasma humano para controlar a infecçáo por Trypanosoma evansi em camundongos. O plasma foi oriundo de um homem aparentemente saudável, com idade entre 27 anos e tipo de sangue A+. Foi detectada uma concentração de $100 \mathrm{mg} \cdot \mathrm{dL}^{-1}$ de apolipoproteína L1 (APOL1) no plasma. Quarenta camundongos foram divididos em quatro grupos, contendo dez animais cada. Grupo A, composto de animais não infectados. Os roedores dos grupos $\mathrm{B}, \mathrm{C}$ e D foram inoculados intraperitonealmente com um isolado de T. evansi. O Grupo B foi usado como um controle positivo. Três dias pós-infecção (DPI), os camundongos foram tratados com plasma humano. Uma dose única de $0,2 \mathrm{~mL}$ de plasma foi administrada nos roedores do grupo $\mathrm{C}$. Os ratos do grupo $\mathrm{D}$ receberam cinco doses de $0,2 \mathrm{~mL}$ de plasma em intervalos de 24 horas. Os ratos do grupo $\mathrm{B}$ apresentaram parasitemia crescente, o que ocasionou a morte dos animais em 5 DPI. Ambos os tratamentos foram capazes de eliminar o parasito do sangue e aumentar a longevidade dos animais. O método da PCR detectou uma eficácia de 50\% (grupo C) e 80\% (grupo D) no tratamento com plasma humano. Este sucesso terapêutico obtido nos animais do grupo D provavelmente foi por receber maiores níveis de APOL1, comparado ao grupo C.

Palavras-chave: Trypanosoma evansi, tratamento, plasma humano, APOL1.

\footnotetext{
*Corresponding author: Aleksandro Schafer Da Silva

Departamento de Microbiologia e Parasitologia,

Universidade Federal de Santa Maria - UFSM, Prédio 20, Sala 4232,

Campus Universitário, Camobi, CEP 97105-900, Santa Maria, RS, Brasil

e-mail: aleksandro_ss@yahoo.com.br
} 


\section{Introduction}

Trypanosoma evansi is a widely distributed hemoflagellate parasite that affects domestic and wild mammals. Since its adaptation to mechanical transmission by bloodsucking insects (tabanids), this parasite has spread beyond its original distribution in sub-Saharan Africa and is now also found in South America, North Africa, and large parts of Asia (HOARE, 1972). Humans were considered to be refractory to T. evansi infection (VANHAMME et al., 2003); however, a case of human infection due to a lack of apolipoprotein was reported for the first time in 2005 in an Indian farmer (JOSHI et al., 2005).

Human innate immunity against Trypanosoma brucei brucei is due to the trypanolytic activity of a human-specific apolipoprotein bound to high-density lipoproteins, known as apolipoprotein L1 (APOL1) (VANHAMME et al., 2003). APOL1 is absorbed by the parasite by endocytosis and triggers the formation of anion selective pores in the lysosomal membrane, which induces uncontrolled osmotic swelling of this compartment and subsequently cell death (PÉREZ-MORGA et al., 2005; PAYS et al., 2006; VANHOLLEBEKE et al., 2006). The trypanolytic activity of proteins as APOL1 and therapies involving human blood for the control of T. brucei infections were described by Pays and Vanhollebeke (2008). Researchers investigated the presence of this protein in the serum of an infected farmer who had high parasitemia and clinical signs of trypanosomosis. The results indicated an absence of APOL1, which is responsible for the trypanolytic activity seen in the human serum (VANHOLLEBEKE et al., 2006).

Studies revealed that trypanosome isolates belonging to the Trypanozoon subgroup were sensitive to therapy using human plasma (HAWKING, 1978; VANHOLLEBEKE et al., 2006). Recently, our research group found that mice infected with T. evansi when treated with human plasma and blood can eliminate the parasite from circulation (OTTO et al., 2010). Given these results, this study aimed to test an alternative protocol with human plasma to control T. evansi infection in mice.

\section{Materials and Methods}

A strain of T. evansi originated from a naturally infected dog (COLPO et al., 2005) was used in this study. One rat was infected intraperitoneally with blood cryopreserved in liquid nitrogen containing $3.4 \times 10^{6}$ parasites/animal to obtain a large amount of parasites for blood inoculation of experimental groups.

Plasma from an apparently healthy 27-year-old male, blood type A+ was used. Blood was collected by a pharmacist and stored in tubes containing anticoagulant (10\% EDTA) and tubes without anticoagulant. A sample of blood with EDTA was centrifuged to separate plasma, which was stored in tubes in liquid nitrogen to be experimentally tested in mice. A blood count (red cell and white cell count) was performed to evaluate the male individual's health condition. Serum was obtained for biochemistry (high-density lipoprotein [HDL], cholesterol, triglycerides, glucose, blood urea nitrogen, creatinine, alanine aminotransferase and alkaline phosphatase). No abnormal results were found in the laboratory tests, so the plasma from a healthy man, who did not use any drugs in the preceding 30 days, was used in this study.

For quantification of plasma APOL1 a quantitative sandwich enzyme-linked immunosorbent assay (ELISA) with monoclonal antibodies specific for APOL1 (anti-APOL1 antibody produced in goat - Sigma) in an ELISA plate was used. Samples $(100 \mu \mathrm{L})$, the standards and a combined enzymelinked peroxidase forming an antibody-antigen-antibody conjugate were pipetted. Subsequently, the plate was washed in a plate washer (Awareness ${ }^{\oplus}$ ) to remove any unbound matter. Then, a solution containing substrate (tetramethylbenzidine + hydrogen peroxide) was added, and color development was proportional to the amount of APOL1 linked. The reaction was stabilized by adding sulfuric acid $(2 \mathrm{~N})$ and color intensity was measured by the ELISA reader $\left(\right.$ Biotek $\left.^{\oplus}\right)$. APOL1 results were expressed as $\mathrm{mg} \cdot \mathrm{dL}^{-1}$ and all calculations were made with a standard curve as a reference, following the manufacturer's instructions, using SPSS version 10.0.

Forty female mice aged 60 days and weighing on average $25 \pm 0.2 \mathrm{~g}$ were used in the study. The animals were kept in cages with 10 animals each in an experimental room with controlled temperature and humidity conditions $\left(25^{\circ} \mathrm{C} ; 70 \%\right)$. They were fed with commercial ration and water ad libitum. All animals underwent a 15-day adaptation period. The study project was approved by the Animal Welfare Committee of Federal University of Santa Maria (UFSM), number 91/2009.

The mice were divided into four groups with 10 animals each. Group A comprised uninfected animals (negative control). The mice from groups B, C and D were inoculated intraperitoneally with $0.1 \mathrm{~mL}$ blood from a rat previously infected with T. evansi containing $1.2 \times 10^{6}$ trypanosomes. Group $\mathrm{B}$ was used as a positive control (i.e., infected and untreated). A single dose of $0.2 \mathrm{~mL}$ plasma was administered intraperitoneally in the rodents in the group C at 3 DPI (day post infection). The mice in the group $\mathrm{D}$ were given intraperitoneally five doses of $0.2 \mathrm{~mL}$ plasma with 24 hours interval between the doses at 3 to 7 DPI. Means and standard deviations of the prepatent period, longevity, mortality and effectiveness of therapy with human plasma in mice experimentally infected with $T$. evansi were estimated. The presence and degree of parasitemia were determined daily for each animal by examining blood smears. A drop of blood was collected from the tail and placed on a slide, and a thin blood smear was prepared manually. Blood smears were Romanovsky (Panotico Rapido ${ }^{\odot}$ ) stained and then examined under a microscope, counting 10 microscopic fields at $1000 \times$ magnification (SILVA et al., 2006) during the 60 days of experiment.

At the end of a 60-day period, the mice surviving the infection (groups $\mathrm{C}$ and D) were randomly selected for examining T. evansi DNA in their brain and blood by PCR. For this assay, brain and blood were individually transferred to sterile tubes containing $0.5 \mathrm{~mL}$ ethanol. For preparation of DNA templates, a small $(0.4 \times 0.4 \mathrm{~mm})$ brain specimen and blood sample were taken, transferred to sterile tubes, and washed three times ( 5 minutes each) in bi-distilled water under shaker. Then, brain were sectioned into small fragments, incubated with lysis buffer (1\% SDS, $100 \mathrm{mM}$ EDTA pH 8.0, $20 \mathrm{mM}$ Tris- $\mathrm{HCl}, \mathrm{pH} 8.0$, and $350 \mathrm{mg} \cdot \mathrm{mL}^{-1}$ proteinase $\mathrm{K}$ ), at $37^{\circ} \mathrm{C}$ for 18 hours, centrifuged at $14000 \mathrm{~g}$ for 5 minutes, and DNA purified using Wizard Purification Systems 
(Promega, USA). Purified DNA samples from brain and blood were used as templates for PCR amplifications of a spliced leader gene sequence using primers and reaction conditions described previously (VENTURA et al., 2002). Amplified DNA fragments were resolved on $2 \%$ agarose gel, stained with ethidium bromide and visualized under ultraviolet (UV) light.

The results of the prepatent period and longevity were subjected to an one-way analysis of variance (ANOVA) followed by Tukey's test. $\mathrm{P}<0.05$ was set as the level of significance for the analyses.

\section{Results}

The concentration of APOL1 in human plasma was $100 \mathrm{mg} \cdot \mathrm{dL}^{-1}$, which is below the reference values for males $\left(107-214 \mathrm{mg} \cdot \mathrm{dL}^{-1}\right.$; commercial kit range values). In mice infected with T. evansi, the prepatent period ranged between 1 and $2 \mathrm{DPI}$. All animals from groups $\mathrm{C}$ and $\mathrm{D}$ showed between three and eight parasites/field at a $1000 \times$ magnification at the beginning of plasma therapy (Figure 1). The mice from group B (untreated) showed increased parasitemia and died within 5 DPI (Table 1), with more than 150 trypanosomes/field (1000x). All animals from groups C and D had negative blood smears at $4 \mathrm{DPI}$ (Figure 1). Rodents from group $\mathrm{D}$ as well as seven animals from group $\mathrm{C}$ had negative smears during the entire experiment period. Nevertheless, three mice from group $\mathrm{C}$ had recurrent parasitemia and died showing high levels of blood parasites during the experiment (Table 1). Of the seven surviving animals with negative blood smears in the group $\mathrm{C}$, two were positive for T. evansi. Of the 10 mice in the group D, two were PCR positive for the parasite. Therefore, an efficacy of 50 and $80 \%$ was found for groups $\mathrm{C}$ and $\mathrm{D}$, respectively (Table 1).

\section{Discussion}

Our research group has investigated in recent years alternative treatments for T. evansi infection because chemotherapy with diminazene aceturate and suramim used in the treatment of trypanosomosis has proved ineffective in many cases (TUNTASUVAN et al., 2003; SILVA et al., 2008b; SILVA et al., 2010). Studies have demonstrated that these drugs have limited effectiveness because they do not cross the blood-brain barrier, thereby creating a potential refuge for trypanosomes during the systemic phase of drug action (JENNINGS et al., 1977; SPINOSA et al., 1999). Therefore, research with herbal medicines, immunotherapy and new chemical compounds are needed to fight T. evansi (SILVA et al., 2010).

T. brucei and T. evansi are both sensitive to treatment with human plasma (VANHOLLEBEKE et al., 2006; OTTO et al., 2010). Researchers have used plasma therapy from different hosts to treat trypanosomosis (WECHSLER; KONGSHAVN, 1988; OTTO et al., 2009). Studies have shown that rabbits are very resistant to T. evansi infection (UCHE et al., 1992; SILVA et al., 2007; 2008a), but this resistance is not yet clear. It is probably associated with proteins with trypanocidal activity found in
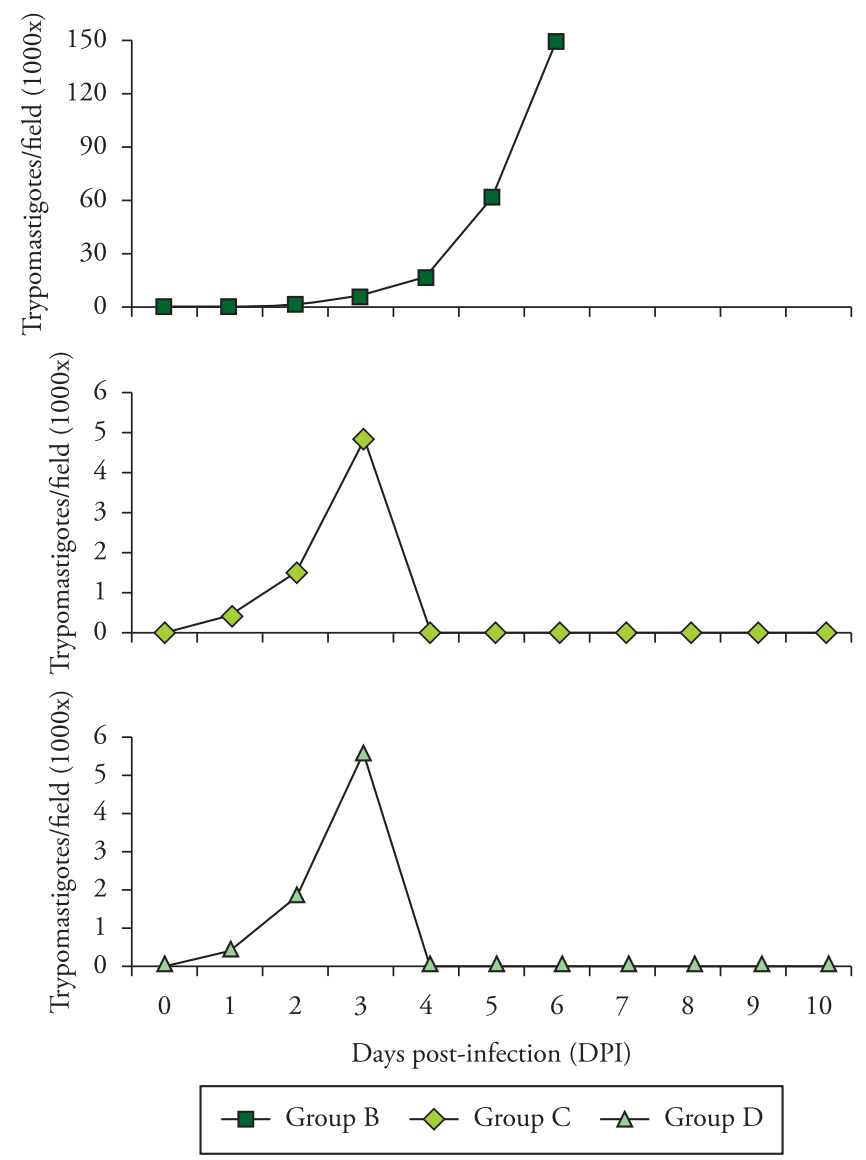

Figure 1. Parasitemia of mice during the first 10 days of experiment (groups B, C and D). Rodents in the group B died within 4 and 6 days post-infection. The mice in the groups $\mathrm{C}$ and $\mathrm{D}$ showed negative blood smears after the first dose of therapy (4 DPI).

Table 1. Means and standard deviation of the prepatent period, longevity, mortality and therapeutic success using treatment with human plasma in mice experimentally infected with T. evansi.

\begin{tabular}{clcccc}
\hline $\begin{array}{c}\text { Groups } \\
\mathbf{n}=\mathbf{1 0}\end{array}$ & \multicolumn{1}{c}{ Treatment } & $\begin{array}{c}\text { Prepatent } \\
\text { period }\end{array}$ & Longevity & $\begin{array}{c}\text { Mortality } \\
\text { *Therapeutic success } \\
(\%)\end{array}$ \\
\hline A & Negative control & - & $60.0^{\mathrm{a}}( \pm 0.0)$ & $0 / 10$ & - \\
B & Positive control & $1.3^{\mathrm{a}}( \pm 0.48)$ & $5.3^{\mathrm{c}}( \pm 0.5)$ & $10 / 10$ & - \\
C & Single dose of plasma & $1.1^{\mathrm{a}}( \pm 0,31)$ & $51.3^{\mathrm{a}}( \pm 14.3)$ & $3 / 10$ & 50.0 \\
D & Five doses of plasma & $1.2^{\mathrm{a}}( \pm 0.42)$ & $60.0^{\mathrm{a}}( \pm 0.0)$ & $0 / 10$ & 80.0 \\
\hline
\end{tabular}

Means followed by same letters in the same column do not differ significantly. ${ }^{*}$ Therapeutic success was considered when the animals survived for 60 days with blood smears and PCRs negative for T. evansi. 
the plasma of rabbits as well as APOL1 in humans (PÉREZMORGA et al., 2005).

In this study, no parasites were found within 24 hours after human plasma administration (4 DPI), as reported by Otto et al. (2010, 2011). The current study quantified APOL1 in human plasma and therefore it is believed that this plasma protein is responsible for the control of parasitemia through a parasite lytic mechanism as described by Pérez-Morga et al. (2005). Studies have reported that haptoglobin protein and apolipoprotein A1 (APOA1) are also components of the two trypanolytic factors in human serum (TOMLINSON et al., 1997).

According to a previous study, in the blood, most lipids are contained in soluble complexes known as lipoproteins. Highdensity lipoproteins (HDL) are spherical particles that comprise a hydrophobic lipid core (which mainly consists of triglycerides and cholesteryl esters) surrounded by a hydrophilic layer (which consists of phospholipids, unesterified cholesterol and several proteins that are collectively known as apolipoproteins). In terms of protein content, HDL particles mainly contain APOA1, which specifically captures and solubilizes free cholesterol, thereby enabling HDL particles to function as cholesterol scavengers. Several HDL-particle subfractions can be separated on the basis of density. The subfraction known as HDL3, which contains both APOL1 and haptoglobinrelated protein, is the densest one. The high protein content of HDL particles makes them denser than other lipoprotein particles, including low-density lipoprotein (LDL) particles (PAYS et al., 2006). A previous study proposed an alternative mechanism for trypanolysis: lytic HDL particles generate cation-selective pores that are active in the plasma membrane after being recycled from the lysosome (DEL PILAR MOLINA-PORTELA et al., 2005). Therefore, given the relationship between trypanocidal activity and lipid metabolism, biochemical parameters of the blood sample used in this study were measured as described in methods to rule out any interference in the production of APOL1. The sample analysis did not show any abnormalities in the sample used. Thus, we believe that the effectiveness of treatment in mice is associated to the lipoproteins as described in the literature.

The administration of human plasma in mice infected with T. evansi showed curative efficacy with a single dose (group C) and five doses (group D). Considering that the same plasma sample was used for both groups, the different therapeutic protocols included different amounts of plasma administered and therefore more APOL1 protein with trypanocidal activity (VANHAMME et al., 2003), which led to a higher cure rate. The therapeutic success seen in the group D was probably due to higher levels of APOL1 used for treating mice infected with T. evansi.

The recurrence of parasitemia in some animals of group C during the study can be related to resistance, as described for other trypanosomes. In contrast to $T$. $b$. brucei, the subspecies T. b. gambiense and T. $b$. rhodesiense escaped the trypanolytic activity of human serum and caused sleeping sickness, a lethal disease in humans. T. b. gambiense is permanently resistant to human serum (van MEIRVENNE et al., 1976; PAYS et al., 2006). Following the injection of these mice with human serum, $T$. b. rhodesiense regains resistance to lysis, and this acquisition of resistance was shown to be associated with antigenic variation (van MEIRVENNE et al. 1976). The trypanocidal effect of treatment with human plasma on T. evansi was evident, and the parasite was cleared from the circulation within 24 hours after therapy, but in experiments with rats infected with T. evansi and treated with different plasmas, no curative efficacy was seen (OTTO et al., 2011).

We conclude that our therapeutic protocol for T. evansi with five doses of human plasma has a higher cure rate when compared to a single dose of plasma as seen in this study and other studies (OTTO et al., 2010, 2011).

\section{Acknowledgements}

We would like to thank Dr Marta Maria Geraldes Teixeira and Dr Herakles Antonio Garcia Perez of University Federal de São Paulo for their help in processing samples by PCR for confirmation of treatment effectiveness.

\section{References}

Colpo CB, Monteiro SG, Stainki DR, Colpo ETB, Henriques GB. Infecção Natural por Trypanosoma evansi em cão no Rio Grande do Sul. Cienc Rural 2005; 35(3): 717-719. http://dx.doi.org/10.1590/S010384782005000300038

Del Pilar Molina-Portela M, Lugli EB, Recio-Pinto E, Raper J. Trypanosome lytic factor, a subclass of high-density lipoprotein, forms cation-selective pores in membranes. Mol Biochem Parasitol 2005; 144(2): 218-226. PMid:16202458. http://dx.doi.org/10.1016/j.molbiopara.2005.08.018

Hawking F. The resistance of Trypanosoma congolense, T. vivax and T. evansi to human plasma. Trans R Soc Trop Med Hyg 1978; 72(4): 405-407. http://dx.doi.org/10.1016/0035-9203(78)90136-0

Hoare CA. The Trypanosomes of Mammals: A Zoological Monograph. Blackwell: Oxford; 1972.

Jennings FW, Whitelaw DD, Urquhart GM. The relationship between duration of infection with Trypanosoma brucei in mice and the efficacy of chemotherapy. Parasitol 1977; 75(2): 145-153.

Joshi PP, Shegokar VR, Powar RM, Herder S, Katti R, Salkar HR et al. Human trypanosomosis caused by Trypanosoma evansi in India: The first case report. Am J Trop Med Hyg 2005; 73(3): 491-495. PMid:16172469.

Otto MA, Da Silva AS, Gressler LT, Dall'Algnol LP, Bottam J, Zanette RA et al. Trypanosoma evansi: therapy with human plasma in infected rats. Comp Clin Pathol2011; 20(2): 139-141. http://dx.doi.org/10.1007/ s00580-010-0968-7

Otto MA, Da Silva AS, Gressler LT, Farret MH, Tavares KC, Zanette RA et al. Susceptibility of Trypanosoma evansi to human blood and plasma in infected mice. Vet Parasitol 2010; 168(1-2): 1-4. PMid:19939570. http://dx.doi.org/10.1016/j.vetpar.2009.10.020

Otto MA, Faccio L, Soares JF, Soares CDM, Gressler LT, Bess F et al. Plasma de coelhos no controle da infecção por Trypanosoma evansi em ratos. Vet Zootec 2009; 16(2): 379-384.

Pays E, Vanhollebeke B, Vanhamme L, Paturiaux-Hanocq F, Nolan DP, Pérez-Morga D. The trypanolytic factor of human serum. Nat Rev Microbiol 2006; 4(6): 477-486. http://dx.doi.org/10.1038/nrmicro1428

Pays E, Vanhollebeke B. Mutual self-defence: the trypanolytic factor story. Microb infect 2008; 10(9): 985-989. 
Pérez-Morga D, Vanhollebeke B, Paturiaux-Hanocq F, Nolan DP, Lins L, Homblé F et al. Apolipoprotein L-I promotes trypanosome lysis by forming pores in lysosomal membranes. Science 2005; 309(5733): 469-472. PMid:16020735. http://dx.doi.org/10.1126/science.1114566

Silva AS, Andrade-Neto OAS, Costa MM, Wolkmer P, Mazzantti CM, Santurio JM et al. Tripanossomose em equinos na região sul do Brasil. Acta Sci Vet 2010; 38(2): 113-120.

Silva AS, Costa MM, Cargnelutti JF, Lopes STA, Monteiro SG. Alterações bioquímicas em coelhos infectados experimentalmente pelo Trypanosoma evansi. Rev Bras Parasitol Vet2007; 16(1): 43-46. PMid:17588322.

Silva AS, Costa MM, Cargnelutti JF, Lopes STA, Monteiro SG. Alteraçôes hematológicas em coelhos infectados experimentalmente pelo Trypanosoma evansi. Ciênc Rural 2008a; 38(2): 538-542. http://dx.doi. org/10.1590/S0103-84782008000200040

Silva AS, Doyle RL, Monteiro SG. Método de contenção e confecção de esfregaço sanguíneo para pesquisa de hemoparasitas em ratos e camundongos. FZVA 2006; 13(2): 153-157.

Silva AS, Tochetto C, Zanette RA, Pierezan F, Rissi DR, Santurio JM et al. Aceturato de diminazeno e dipropionato de imidocarb no controle de infecção por Trypanosoma evansi em Rattus norvegicus infectados experimentalmente. Cienc Rural 2008b; 38(5): 1357-1362. http://dx.doi. org/10.1590/S0103-84782008000500025

Spinosa HS, Górniak SL, Bernardi MM. Farmacologia aplicada à medicina veterinária. Rio de Janeiro: Guanabara koogan; 1999.

Tomlinson S, Muranjan M, Nussenzweig V, Raper J. Haptoglobin-related protein and apolipoprotein $\mathrm{AI}$ are components of the two trypanolytic factors in human serum. Mol Biochem Parasitol 1997; 86(1): 117-120. PMid:9178275.
Tuntasuvan D, Jarabrum W, Viseshakul N, Mohkaew K, Borisutsuwan $S$, Theeraphan A et al. Chemotherapy of surra in horses and mules with diminazene aceturate. Vet Parasitol 2003; 110(2-3): 227-233. http://dx.doi.org/10.1016/S0304-4017(02)00304-7

Uche UE, Jones TW, Boid R. Antibody patterns in rabbits showing different levels of susceptibility to an experimental Trypanosoma evansi infection. Acta Trop 1992; 52(2-3): 139-147. http://dx.doi. org/10.1016/0001-706X(92)90030-2

Van Meirvenne N, Magnus E, Janssens PG. The effect of normal human serum on trypanosomes of distinct antigenic type (ETat 1 to 12) isolated from a strain of Trypanosoma brucei rhodesiense. Ann Soc Belg Med Trop 1976; 56(1): 55-63. PMid:1015880.

Vanhamme L, Paturiaux-Hanocq F, Poelvoorde P. Apolipoprotein L-I is the trypanosome lytic factor of human serum. Nature 2003; 422(6927): 83-87. PMid:12621437. http://dx.doi.org/10.1038/nature01461

Vanhollebeke B, Poelvoorde P, Pays A, Joshi PP, Katti R, Jannin JG et al. Human Trypanosoma evansi infection linked to a lack of apolipoprotein L-I. $N$ Engl J Med 2006; 355(26): 2752-2756. PMid:17192540. http://dx.doi.org/10.1056/NEJMoa063265

Ventura RM, Takeda GF, Silva RA, Nunes VL, Buck GA, Teixeira MM. Genetic relatedness among Trypanosoma evansi stocks by random amplification of polymorphic DNA and evaluation of a synapomorphic DNA fragment for species-specific diagnosis. Int J Parasitol 2002; 32(1): 53-63. http://dx.doi.org/10.1016/S00207519(01)00314-9

Wechsler DS, Kongshavn PA. Further characterization of the curative antibodies in Trypanosoma musculi infection. Infect Immunol 1988; 56(9): 2379-2384. PMid:3410542. PMCid:259576. 